\title{
Biological Composition of Respirable Particulate Matter in an Industrial Vicinity in South Africa
}

\author{
Oyewale Mayowa Morakinyo ${ }^{1,2, *(\mathbb{C})}$, Matlou Ingrid Mokgobu ${ }^{1}$, Murembiwa Stanley Mukhola ${ }^{1}$ \\ and Tshifhiwa Godobedzha ${ }^{3}$ \\ 1 Department of Environmental Health, Faculty of Science, Tshwane University of Technology, Private Bag \\ X680, Pretoria 0001, South Africa; mokgobumi@tut.ac.za (M.I.M.); mukholams@tut.ac.za (M.S.M.) \\ 2 Department of Environmental Health Sciences, Faculty of Public Health, College of Medicine, \\ University of Ibadan, Ibadan 200284, Nigeria \\ 3 Air Quality Management, Environment and Agriculture Management Department, City of Tshwane \\ Municipality Private Bag 440, Pretoria 0001, South Africa; tshifhiwaG@tshwane.gov.za \\ * Correspondence: wahlemirax@gmail.com; Tel.: +27-8460-72767
}

Received: 31 December 2018; Accepted: 18 February 2019; Published: 21 February 2019

\begin{abstract}
There is a growing concern that exposure to particulate matter of aerodynamic diameter of less than $2.5 \mu \mathrm{m}\left(\mathrm{PM}_{2.5}\right)$ with biological composition (bioaerosols) may play a key role in the prevalence of adverse health outcomes in humans. This study determined the bacterial and fungal concentrations in $\mathrm{PM}_{2.5}$ and their inhalation health risks in an industrial vicinity in South Africa. Samples of $\mathrm{PM}_{2.5}$ collected on a 47-mm glass fiber filter during winter and summer months were analysed for bacterial and fungal content using standard methods. The health risks from inhalation of bioaerosols were done by estimating the age-specific dose rate. The concentration of bacteria $\left(168-378 \mathrm{CFU} / \mathrm{m}^{3}\right)$ was higher than fungi $\left(58-155 \mathrm{CFU} / \mathrm{m}^{3}\right)$. Bacterial and fungal concentrations in $\mathrm{PM}_{2.5}$ were lower in winter than in the summer season. Bacteria identified in summer were similar to those identified in winter: Staphylococcus sp., Bacillus sp., Micrococcus sp., Flavobacterium sp., Klebsiella sp. and Pseudomonas sp. Moreover, the fungal floras identified include Cladosporium spp., Aspergillus spp., Penicillium spp., Fusarium spp. and Alternaria spp. Children inhaled a higher dose of bacterial and fungal aerosols than adults. Bacteria and fungi are part of the bioaerosol components of $\mathrm{PM}_{2.5}$. Bioaerosol exposure may present additional health risks for children.
\end{abstract}

Keywords: particulate matter; bioaerosols; air quality; dose rate; health effects; South Africa

\section{Introduction}

Urban air quality in most countries in sub-Saharan Africa is quickly deteriorating mainly due to rapid industrial and population growth [1]. South Africa is one of the largest industrialized economies in the Southern Hemisphere with significant mining and metallurgical activities [2]. It is also an energy and carbon-intensive economy with abundant coal reserves valued at $4 \%$ of the world's total deposits [3]. It is an arid country with high naturally-occurring dust levels, coupled with emissions from industrial and vehicular pollution [4].

South Africa often experiences high air pollution levels that are injurious to human health, mainly in large industrial areas such as the South Durban Industrial Basin and the Vaal Triangle [5]. The Highveld Plateau region accounts for $75 \%$ of industrial facilities and is responsible for about $90 \%$ of planned emissions of industrial dust, nitrogen oxides and sulphur dioxide in the country [6]. The total estimated annual emission of particulate matter (PM) in the region is 279,630 tons. The emission of $\mathrm{PM}$ arising from metallurgical industries accounts for $17 \%$ of the total emission. The most commonly reported air pollutants in South Africa include $\mathrm{PM}, \mathrm{CO}$, oxides of nitrogen $\left(\mathrm{NO}_{\mathrm{x}}, \mathrm{SO}_{2}, \mathrm{O}_{3}\right.$ and $\mathrm{Pb}$ [7]. 
In South Africa, the standard for $\mathrm{PM}_{2.5}$ was established in the year 2012 in section 9(1) of the National Environmental Management Act (NEMA): Air Quality Act (AQA) as $40 \mu \mathrm{g} / \mathrm{m}^{3}$ and $20 \mu \mathrm{g} / \mathrm{m}^{3}$ per day and annual average respectively [8]. However, there is no existing legislation governing microbiological standards for air pollution in South Africa. The need to conduct research that will determine the required bio-pollutant levels in $\mathrm{PM}_{2.5}$ is of public health importance.

$\mathrm{PM}$ with an aerodynamic diameter less than 2.5 microns $\left(\mathrm{PM}_{2.5}\right)$ has garnered wide consideration in recent years and has elicited a wide range of biological responses. $\mathrm{PM}_{2.5}$ originates mainly from anthropogenic activities involving vehicular emissions, ground fossil fuel combustion, burning of biomass fuel, construction work, quarrying and mining, agriculture and dust from roads [9]. Owing to its small size, large surface area, penetration ability, deposition, bioavailability and long residence time in the air, $\mathrm{PM}_{2.5}$ can penetrate the human respiratory tract [10]. This makes $\mathrm{PM}_{2.5}$ more toxic to humans than other common air pollutants [11]. Epidemiological studies [12,13] and toxicological studies $[9,14]$ have associated short- and long-term exposure to $\mathrm{PM}_{2.5}$ with a range of adverse health endpoints from acute respiratory infections to untimely deaths. $\mathrm{PM}_{2.5}$ is a recognized group 1 carcinogen by the World Health Organization (WHO) and the International Agency for Research on Cancer (IARC) [15]. New evidence suggests possible associations between long-term $\mathrm{PM}_{2.5}$ exposure and neurodevelopment, cognitive function and chronic disease conditions such as diabetes in humans [16].

$\mathrm{PM}_{2.5}$ is a heterogeneous mix of solid and liquid particles including chemical and biological fractions [17]. A substantial component of $\mathrm{PM}_{2.5}$ in indoor and outdoor environments are bioaerosols [18]. Bioaerosols are solid or liquid particles carrying living organisms from biological sources, with sizes ranging from $0.1 \mathrm{~mm}$ to $100 \mathrm{~mm}$ in diameter $[19,20]$. They include fungi, bacteria, viruses, endotoxin and pollens that originate from terrestrial and marine environments during biological processes [21]. Bioaerosols are present in the atmosphere as individual organisms, or are attached to PM, dust or water droplets [22]. About $5-10 \%$ of total atmospheric particles are suspended PM and about $24 \%$ are made up of bioaerosols [23].

Bioaerosols vary in size and structure and their diversity is dependent on their source and other prevailing environmental conditions [24]. Bioaerosols get attached to PM to derive their nutrients and be shielded from ultraviolet radiation [25]. Bioaerosols can alter atmospheric chemistry and nucleation processes and interact with ecosystems and human health [26].

The presence of bioaerosols in the air undoubtedly poses a health risk. Researchers have indicated that both viable and non-viable airborne bioaerosols have the potential to cause or aggravate health problems in exposed individuals $[27,28]$. Health outcomes associated with exposure to bioaerosols have been documented in many studies. For instance, bioaerosols have been implicated in the causality of some non-infectious airway diseases such as hypersensitivity pneumonitis [28], organic dust syndrome, allergies, asthma and rhinitis [29-32]. Exposure to bioaerosols can trigger exacerbation of asthma and wheeze in both children and adults $[33,34]$. Bioaerosols have been linked to the impairment of lung function $[35,36]$ and the pathogenesis of pulmonary diseases [37,38], such as chronic obstructive pulmonary disease [39] and severe lung damage [40]. The WHO reported that respiratory tract infections are the foremost cause of death in low-income countries and the 4th leading cause of death in the middle and high-income countries [41].

In South Africa, limited studies have determined the levels of $\mathrm{PM}_{2.5}$ originating from an industrial area and the possible risks that could occur from human exposure to its biological contents. There is a growing concern that exposure to microbial bioaerosols may play a key role in the adverse health outcomes in humans [18]. Moreover, there is a dearth of studies in South Africa on the health-related outcomes after exposure to $\mathrm{PM}_{2.5}$-bound bioaerosols. A better understanding of the biological component of $\mathrm{PM}_{2.5}$ is crucial to bridging the knowledge gap in air pollution and its associated health effects. Therefore, this study determined the bacterial and fungal concentrations in $\mathrm{PM}_{2.5}$ in an industrial area in Pretoria West, South Africa. 


\section{Materials and Methods}

\subsection{Description of Study Area}

The $\mathrm{PM}_{2.5}$ samples were collected during winter and summer seasons in an industrial area in Pretoria West, South Africa located at $25^{\circ} 44^{\prime} 46^{\prime \prime} \mathrm{S} 28^{\circ} 11^{\prime} 17^{\prime \prime} \mathrm{E}$ (Figure 1).

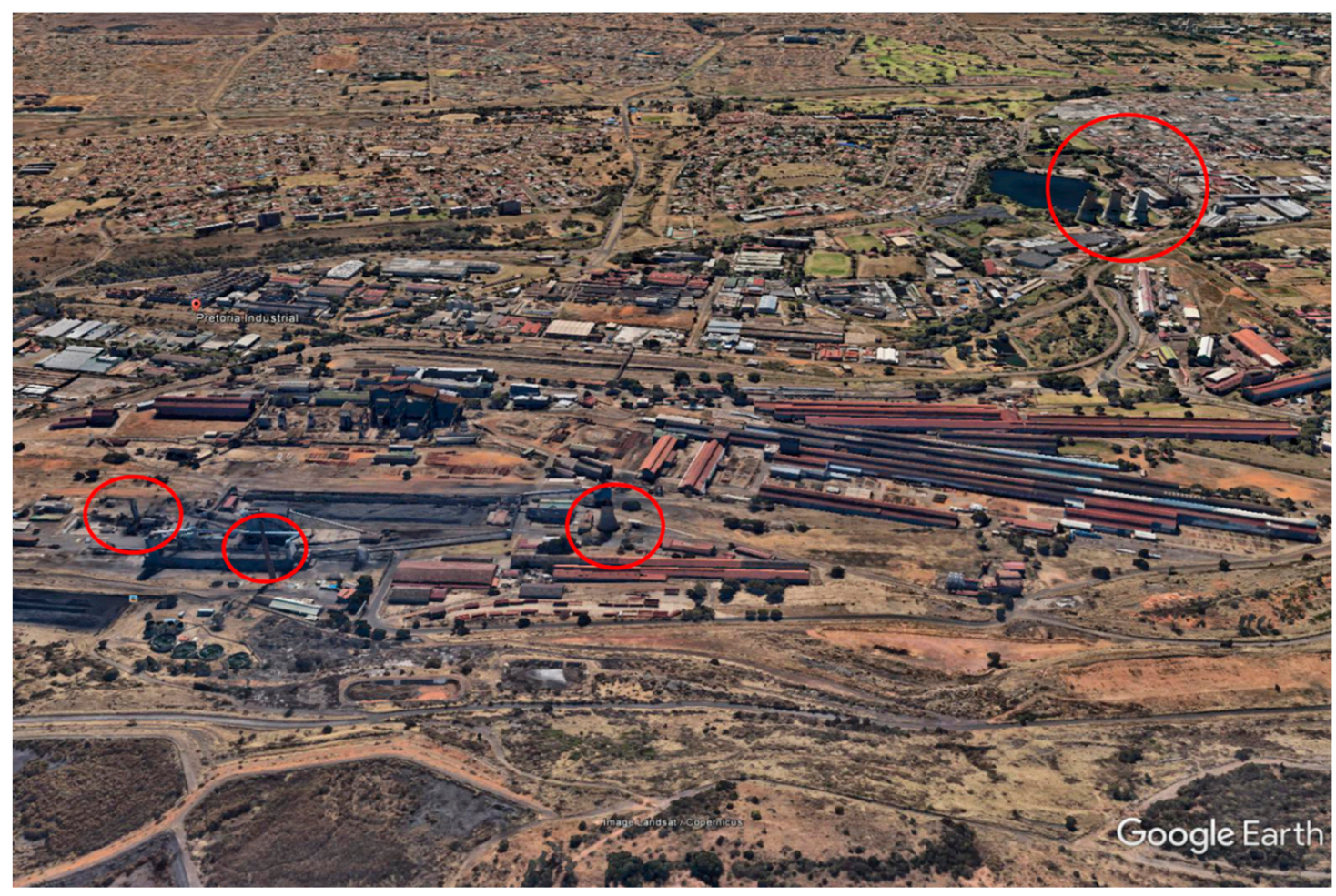

Figure 1. Google Earth image depicting Pretoria West industrial area. The red rings indicate some of the emission stacks in the study area.

Pretoria is situated in the northern part of Gauteng province in the North-Northeast of

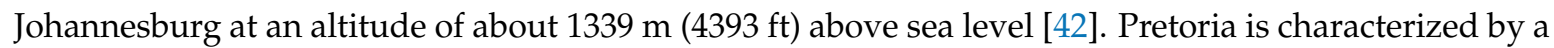
humid subtropical climate of long hot rainy summers and short cool to cold, dry winters. The average annual temperature is $18.7^{\circ} \mathrm{C}\left(65.7^{\circ} \mathrm{F}\right)$ [24]. The detailed description of the study area was reported in previous studies, such as Morakinyo et al. [43,44].

\subsection{Sample Collection}

$\mathrm{PM}_{2.5}$ samples were collected on 47-mm quartz fiber filters (with a porosity of $2 \mu \mathrm{m}$ ) using the Beta ${ }^{\text {PLUS }}$ Particle measurement system (Figure 2) at a flow rate of $12 \mathrm{~L} / \mathrm{min}$ for $24 \mathrm{~h}$. The volume of air sampled was normalized to the area of the filter extracted. In the Beta ${ }^{\text {PLUS }}$ Particle measurement system, filters move from a supply magazine to the sampling position in succession and finally to the storage magazine for retrieval. The monitoring system is a part of the Air Quality Monitoring network of the City of Tshwane at the Pretoria West industrial area and managed by the Environmental Management Services Department. The equipment actively samples $\mathrm{PM}_{2.5}$ in an hourly mode for approximately 57 min. Prior to ambient air sampling, each filter was pre-conditioned for $48 \mathrm{~h}$ in a desiccator before and after sampling in a temperature and relative humidity-controlled room $\left(\mathrm{T}=20 \pm 1{ }^{\circ} \mathrm{C}, \mathrm{RH}=50 \pm 5 \%\right)$. 


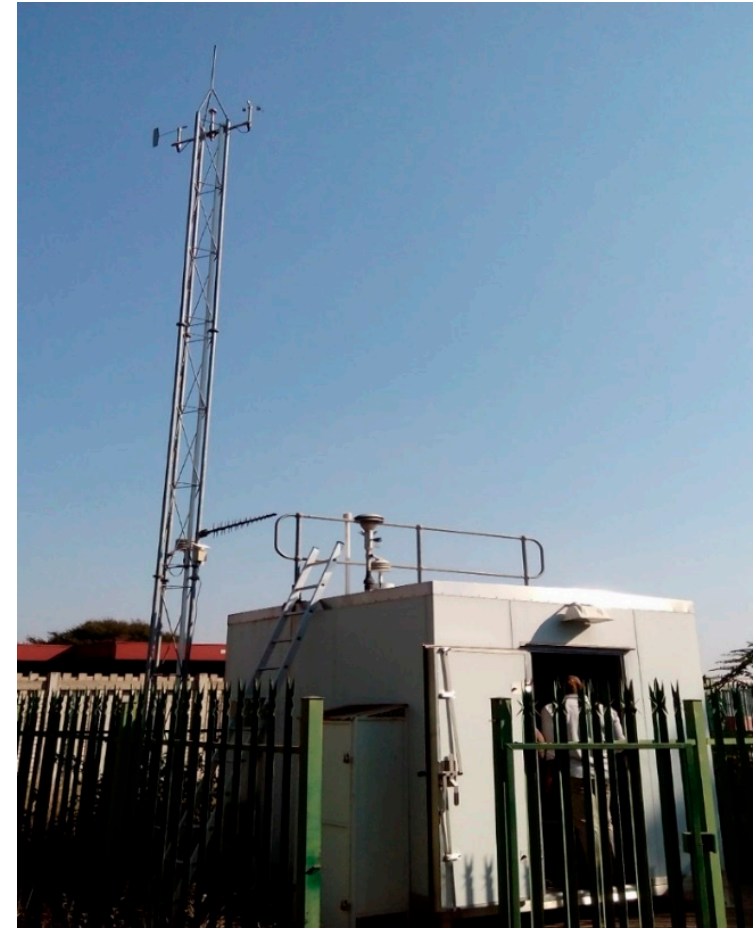

(a)

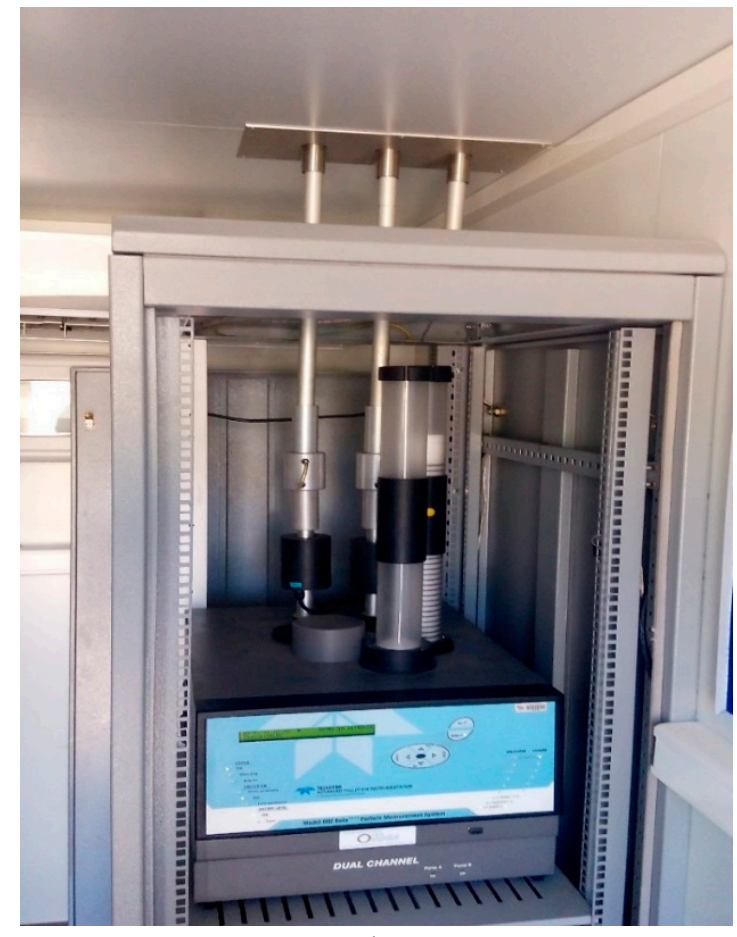

(b)

Figure 2. (a) A monitoring station in Pretoria West; (b) Beta ${ }^{P L U S}$ Particle measurement system.

The $\mathrm{PM}_{2.5}$ samples were collected from 2 January 2016 to 29 February 2016 (summer) and from 1 June 2016 to 31 July 2016 (winter). Overall, 144 filters in four months (i.e., nine filters per week) were used for analysis of the biological content of $\mathrm{PM}_{2.5}$. After sampling was completed, filters were retrieved from the Beta ${ }^{\text {PLUS }}$ Particle measurement system and placed in separate Petri dishes. The filters' gravimetric masses were thereafter estimated using a Sartorius ME5-OCE analytical microbalance according to the European Standard EN 14907 [45]. The difference in filter weight, as well as the volume of air that filtered through each filter, were documented.

\subsection{Filter Analysis}

One-half of each of the quartz filters containing the $\mathrm{PM}_{2.5}$ samples was dissolved in $50 \mathrm{~mL}$ phosphate buffered solution with $0.05 \%$ tween $80(w / v)$, and the mixture was shaken for about one hour. Serial dilutions $\left(10^{-3}\right)$ were prepared in triplicate [46], and $0.5 \mathrm{~mL}$ of each serial dilution was added to Petri plates containing sterile trypticase soy agar for the cultivation of bacteria, and to Petri plates containing sterile malt extract agar for the cultivation of fungi. Bacteria and fungi have been recognized as the primary constituents of $\mathrm{PM}_{2.5}$ [47]. They are the most important bioaerosols spores found in outdoor air [47].

The trypticase soy agar (Sigma-Aldrich, St. Louis, MO, USA) and the malt extract agar (Sigma-Aldrich, St. Louis, MO, USA) were supplemented with 50 ppm of cycloheximide and chloramphenicol respectively to prevent the growth of contaminants. The bacterial aerosols on trypticase soy agar were incubated at $28^{\circ} \mathrm{C}$ for three days while the fungal aerosols on the malt extract agar were incubated at $28^{\circ} \mathrm{C}$ for seven days. Colonies that grew on the media were counted and the mean count was estimated.

The concentration of culturable bacteria and fungi were computed as colony forming units per cubic meter of air $\left(\mathrm{CFU} / \mathrm{m}^{3}\right)$ [48]. The total concentration of cultured bacteria and fungi was computed from the division of the number of colonies counted on the plates by the volume of air sampled [29]. Identification of the bacteria was by morphology and Gram staining [49] while fungal isolates were 
identified based on the observation of micro- and macro-morphological features [46]. Feller's law was used as the correction factor [50] while the quantification limit was set at $10 \mathrm{CFU}$ per plate [51].

In ensuring quality control and minimizing errors, characterisation of bioaerosols in $\mathrm{PM}_{2.5}$ was done according to the PN-EN 12322 standard [52]. Sterility was achieved by incubating culture medium at an optimal temperature for the procedure for at least $72 \mathrm{~h} \mathrm{[49].} \mathrm{Blank} \mathrm{filters} \mathrm{were} \mathrm{carried} \mathrm{to} \mathrm{the} \mathrm{field}$ and loaded into the sampling filter holders as were the filters for sampling, but these blank filters received no air flow from the sampler [53].

\subsection{Dose Rate Estimation}

The dose rate of the bacterial and fungal component associated with $\mathrm{PM}_{2.5}$ was estimated using the United States Environmental Protection Agency (US EPA) model (Equation (1)). The model was developed to assess the risks of environmental exposure for susceptible populations $[49,54,55]$.

$$
\text { Dose rate }(\mathrm{CFU} / \mathrm{kg})=\frac{C * \operatorname{Inh} R * E T}{B W}
$$

where:

- $\mathrm{C}$ is the bacterial and fungal aerosol concentration $\left(\mathrm{CFU} / \mathrm{m}^{3}\right)$;

- InhR is the inhalation rate $\left(\mathrm{m}^{3} /\right.$ day);

- $\quad$ ET is the exposure time (h/day);

- $\quad$ BW is the body weight $(\mathrm{kg})$.

The values used for computing these parameters are presented in Table 1 . The dose rate was calculated using the US EPA's Child-Specific Exposure Factors Handbook [56] and other literature $[57,58]$. The estimation was age specific and divides the population in the study area into four age-specific groups, namely infants (birth- 1 year), children ( $2-5$ years), toddlers (6-12 years) and adults (19-75 years).

Table 1. Recommended values in equations of the daily exposure dose of $\mathrm{PM}_{2.5}$.

\begin{tabular}{|c|c|c|c|c|c|c|}
\hline \multirow[b]{2}{*}{ Parameter } & \multirow[b]{2}{*}{ Definition } & \multicolumn{4}{|c|}{ Value for Age Categories } & \multirow[b]{2}{*}{ Reference } \\
\hline & & $\begin{array}{c}\text { Infant } \\
\text { (0-1 year) }\end{array}$ & $\begin{array}{c}\text { Child } \\
\text { (2-5 years) }\end{array}$ & $\begin{array}{c}\text { Child } \\
\text { (6-12 years) }\end{array}$ & $\begin{array}{c}\text { Adult } \\
\text { (19-75 years) }\end{array}$ & \\
\hline $\mathrm{C}$ & $\begin{array}{c}\text { Mean concentration of } \mathrm{PM}_{2.5} \text { in } \\
\text { ambient air }\left(\mu \mathrm{g} / \mathrm{m}^{3}\right)\end{array}$ & & & & & \\
\hline ET & Exposure time (h) & 1 & 8 & 6 & 3 & {$[59,60]$} \\
\hline InhR & Inhalation rate $\left(\mathrm{m}^{3} /\right.$ day $)$ & 9.2 & 16.74 & 21.02 & 21.4 & {$[60]$} \\
\hline
\end{tabular}

\subsection{Data Analysis}

Graphical representation (wind rose) of the effects of wind speed and wind direction on the concentration of $\mathrm{PM}_{2.5}$ was done using $\mathrm{R}^{\odot}$ (v.2.13.1) statistical software (Bell Laboratories, Murray Hill, NJ, USA). This was used to deduce the dominant prevailing winds in the study area. Descriptive statistics such as mean, standard deviation and percentages were used to summarize the concentration of bacterial and fungal bioaerosols.

\section{Results and Discussion}

\subsection{Frequency of Wind Speed and Direction}

The annual hourly frequency spread of wind speed and direction, spanning the entire period of monitoring, is represented by the wind rose diagram (Figure 3). The concentric circles and the radial dimension of the radius of the wind sector represent the wind speed frequency distribution function [61]. The core of each plot denotes a wind speed of zero, which expands outwardly. As depicted in Figure 3, it is observed that the wind direction is widely distributed, with the west to 
southwest and the east to northeast wind directions dominating. Strong winds that are above $4.0 \mathrm{~m} / \mathrm{s}$ are present in all the sectors. Alghamdi et al. [46] reported that wind speed was positively correlated with bioaerosol-bound PM but negatively correlated with the size of $\mathrm{PM}_{2.5}$. Wind speed is crucial to the survival of airborne microbes. It acts as a dilution factor, through diffusion, by reducing the net concentration of bioaerosols during transportation from the source to sampling point.

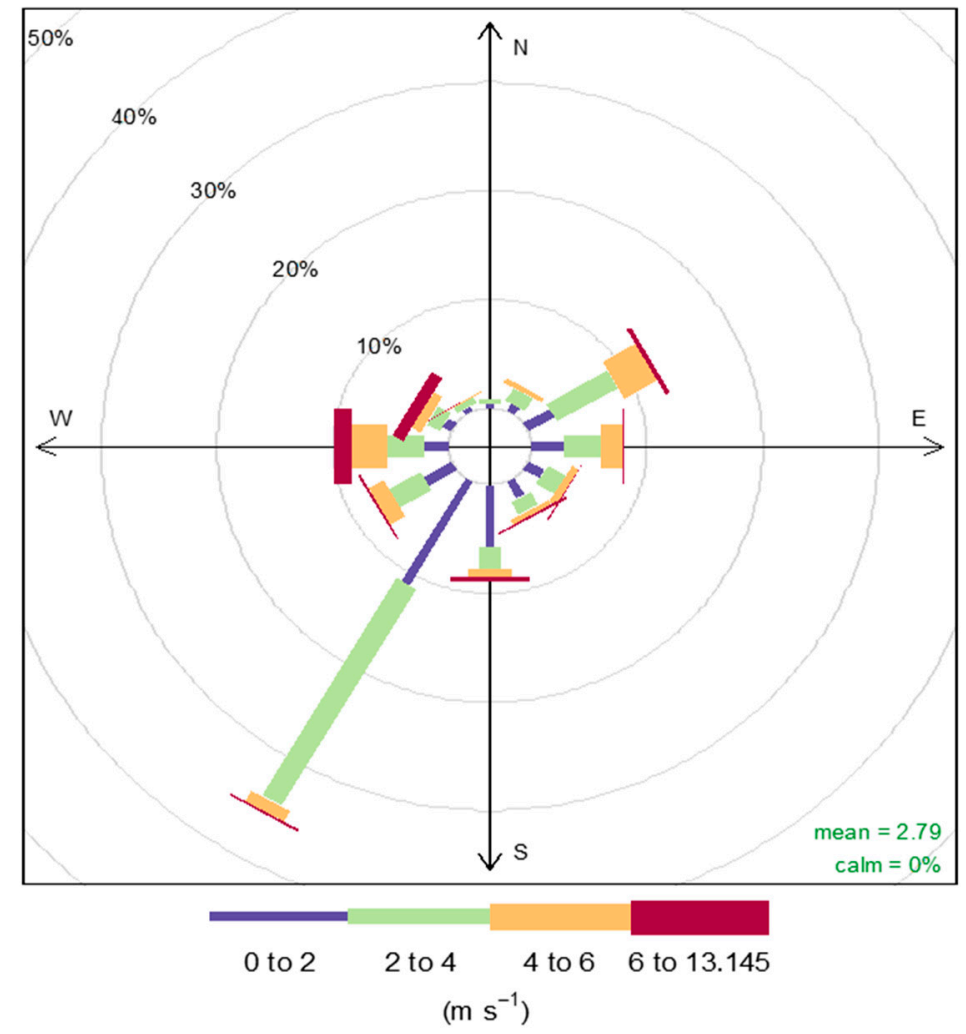

Frequency of counts by wind direction (\%)

Figure 3. Annual wind rose of wind speed and wind direction in Pretoria West.

\subsection{Bacterial and Fungal Concentrations Associated with $P M_{2.5}$}

A higher concentration of bacteria $\left(168-378 \mathrm{CFU} / \mathrm{m}^{3}\right)$ than fungi $\left(58-155 \mathrm{CFU} / \mathrm{m}^{3}\right)$ was recorded. Lighthart [22] and Alghamdi et al. [46] reported a higher concentration of airborne bacteria than fungi in PM. The reduced concentration of fungi recorded in our study may be a result of the characteristics of the study area. This can be attributed to the lack of biotic sources and arid and barren terrains. Instances of a significant decrease in the levels of airborne fungi in hot weather conditions have been reported [46,62]. Other factors that can predict low biological-bound PM include meteorological factors, the composition of the PM, physical and chemical changes, the prevailing air pollution and geographical characteristics [63]. High concentration of toxic chemical compounds in $\mathrm{PM}_{2.5}$ could cause a reduction in its microbial concentration [63]. Figure 4 shows the types and concentration of bacteria and fungi associated with $\mathrm{PM}_{2.5}$. The outdoor airborne bacteria identified in summer were similar to the bacteria found in winter: Staphylococcus spp. had the highest concentration, followed by Bacillus spp. Other bacteria included Micrococcus spp., Flavobacterium spp., Klebsiella spp. and Pseudomonas spp.

However, Pseudomonas spp. was not detected in any of the samples during the winter season. This implies that the concentration of Gram-positive bacteria (Staphylococcus, Bacillus, Micrococcus) in urban air is higher than Gram-negative bacteria (Flavobacterium, Klebsiella, Pseudomonas). This position has been reported by Fang et al. [64] in Beijing, China and by Aydogdu et al. [65] in Edirne, Turkey. The ability of Gram-positive bacteria to survive under the harsh conditions of intense solar radiation, 
dryness and aerosolized chemical pollutants enables their concentration in the atmosphere to exceed that of Gram-negative bacteria [64].

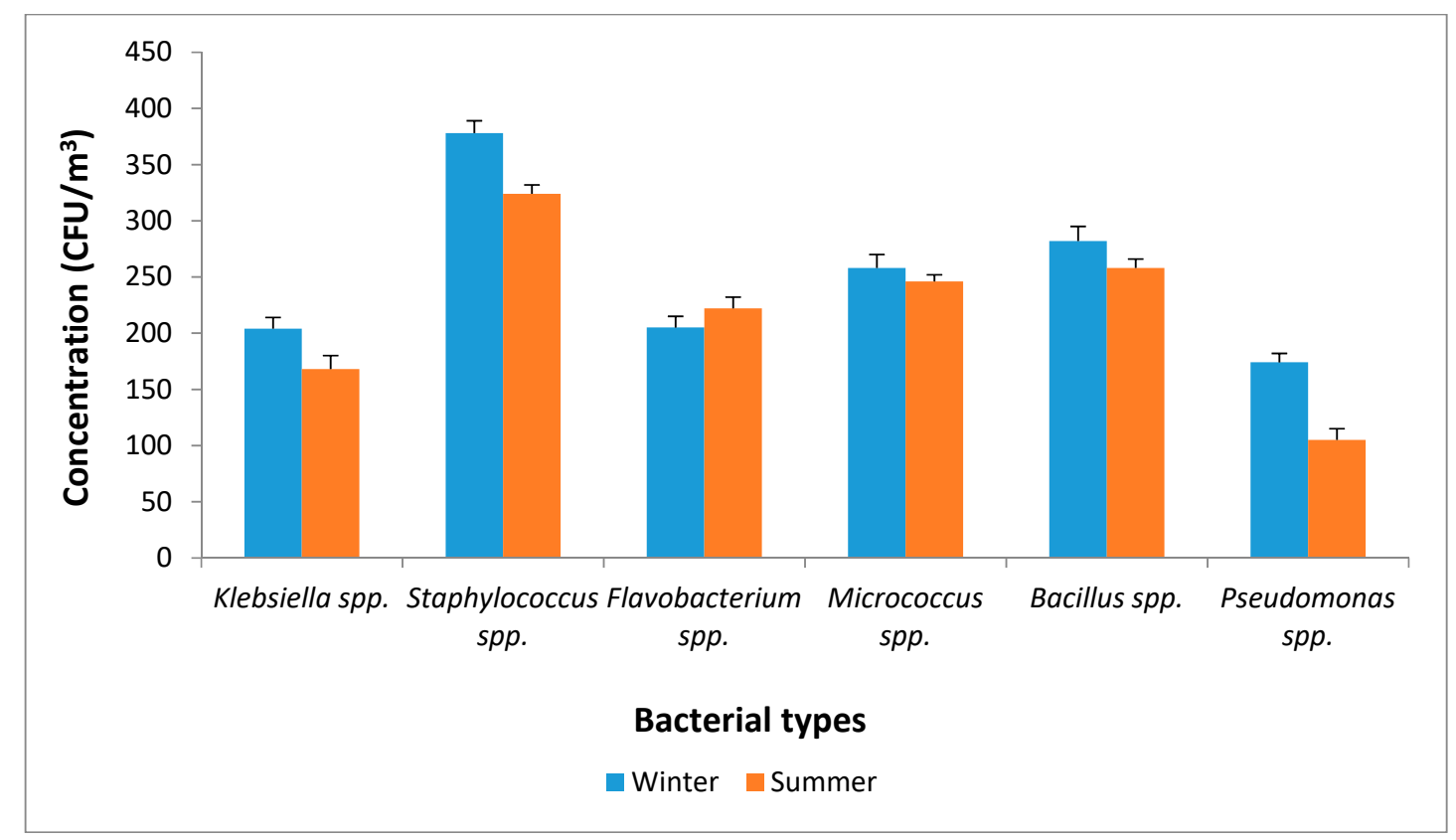

Figure 4. Concentration of isolated bacterial-bound $\mathrm{PM}_{2.5}$ in Pretoria West.

Moreover, the fungal spores identified to be associated with $\mathrm{PM}_{2.5}$ in this study include Cladosporium spp., Aspergillus spp., Penicillium spp., Fusarium spp. and Alternaria spp. Mentese et al., [66] reported that Alternaria, Aspergillus, Cladosporium, Fusarium and Penicillium spores are the prevalent allergic genera. The concentration of Cladosporium spp. in winter and summer $\left(155 \mathrm{CFU} / \mathrm{m}^{3}\right.$ vs. $\left.141 \mathrm{CFU} / \mathrm{m}^{3}\right)$ was higher than that of Aspergillus spp. $\left(150 \mathrm{CFU} / \mathrm{m}^{3}\right.$ vs. $\left.117 \mathrm{CFU} / \mathrm{m}^{3}\right)$, Penicillium spp. ( $95 \mathrm{CFU} / \mathrm{m} 3$ vs. $\left.77 \mathrm{CFU} / \mathrm{m}^{3}\right)$, Fusarium spp. (78 CFU/m3 vs. $62 \mathrm{CFU} / \mathrm{m}^{3}$ ) and Alternaria spp. (72 CFU $/ \mathrm{m}^{3}$ vs. $58 \mathrm{CFU} / \mathrm{m}^{3}$ ) (Figure 5). Cladosporium spp. and Alternaria spp. are known to be outdoor fungi [67].

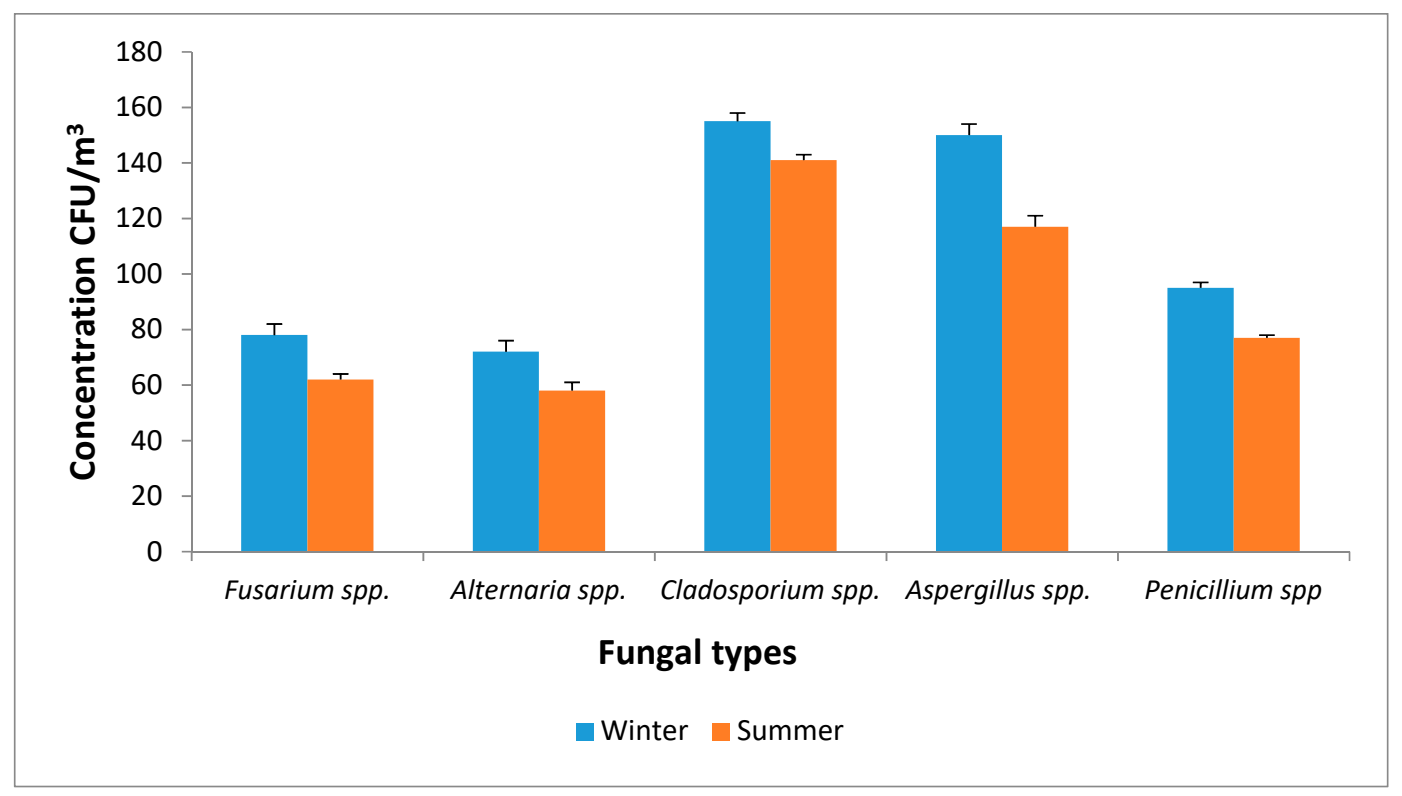

Figure 5. Concentration of isolated fungal-bound $\mathrm{PM}_{2.5}$ in Pretoria West 
This study is consistent with other studies that reported the dominance of Cladosporium, Penicillium, Aspergillus, Alternaria, yeasts and non-sporing isolates in outdoor air [68,69]. Of these types, Cladosporium spp. were more prevalent than the other fungal types that are associated with PM [46,69]. The abundance of Aspergillus, Penicillium and Alternaria in PM was credited with their ability to grow on various substrates and under diverse weather conditions. Also, their prevalence is dependent on their ability to produce and discharge high spore numbers into the atmosphere [70]. Aspergillus and Penicillium species are recognized producers of mycotoxins which are injurious to human health at elevated levels [71]. Hypersensitivity to Aspergillus fumigatus and Penicillium can cause allergic bronchopulmonary, while the persistence and severity of asthma have been linked to human sensitivity to Alternaria and Cladosporium [72].

Although it may be difficult to associate the concentrations of bacterial and fungal types identified in this study with adverse health outcomes, past studies have pointed out the role of these microorganisms in disease causation. Aspergillus spp., Penicillium spp., Alternaria spp. and Cladosporium spp. can induce respiratory conditions such as asthma, allergic rhinitis and hypersensitivity reactions in susceptible individuals [73,74].

Moreover, the lowest bacterial and fungal counts in this study were identified in winter, with the counts being higher in summer. Winter season is synonymous with low ambient temperatures, which in turn affect microbial growth [75]. Low temperatures are not favorable to the growth, reproduction and distribution of microorganisms [76]. A reduced temperature slows down enzymatic action and affects the fluidity of the microbial cell membrane [75]. Moreover, the increased temperatures that are prevalent in summer support the growth and physiological activities of bioaerosols [75].

However, in contrast to the findings of this study, the incidence of higher bacterial and fungal counts in winter than in summer was reported by Li et al. [77] in Northwest China and by Gao et al. [78] in Beijing, China. Researchers are of the view that the survival of bioaerosols in the atmosphere could be hindered by intense solar or ultraviolet radiation exposure that depicts the summer months and hence, the reduction in the abundance of bacterial and fungal counts $[79,80]$.

\subsection{Dose Rate Estimation}

The computed results for the inhaled dose rates of bacteria and fungi in $\mathrm{PM}_{2.5}$ are shown in Table 2. It was observed that children (2-5 years) inhaled a higher dose of bacterial and fungal aerosols in winter and summer than other age groups. Overall, children inhaled significantly higher bacterial and fungal doses than infants and adults. This position has been reported in similar studies $[51,81,82]$. Their higher respiration rates per unit body weight in addition to other behavioral characteristics and physiological features could possibly explain the higher rates among children [83].

Table 2. Age-specific dose rates (CFU/kg/day) of bioaerosols in $\mathrm{PM}_{2.5}$.

\begin{tabular}{ccccccccc}
\hline \multirow{3}{*}{ Season } & \multicolumn{3}{c}{ Dose Rate of Bacterial Aerosols } & \multicolumn{4}{c}{ Dose Rate of Fungal Aerosols } \\
\cline { 2 - 9 } & $\begin{array}{c}\text { Infant } \\
\text { (0-1 year) }\end{array}$ & $\begin{array}{c}\text { Child } \\
\mathbf{( 2 - 5} \text { years) }\end{array}$ & $\begin{array}{c}\text { Child } \\
\mathbf{( 6 - 1 2} \text { years) }\end{array}$ & $\begin{array}{c}\text { Adult } \\
\text { (19-75 years) }\end{array}$ & $\begin{array}{c}\text { Infant } \\
\text { (0-1 year) }\end{array}$ & $\begin{array}{c}\text { Child } \\
\text { (2-5 years) }\end{array}$ & $\begin{array}{c}\text { Child } \\
\text { (6-12 years) }\end{array}$ & $\begin{array}{c}\text { Adult } \\
\text { (19-75 years) }\end{array}$ \\
\hline Winter & 210.1 & 1528.8 & 718.3 & 230.7 & 49.7 & 361.5 & 169.8 & 54.5 \\
Summer & 233.7 & 1700.7 & 799.0 & 256.6 & 63.5 & 462.2 & 217.2 & 69.7 \\
\hline
\end{tabular}

Adverse health outcomes in humans are strongly dependent on the level of absorbed dose [74]. Children are more susceptible to the effects of airborne pollution than adults due to their increased ventilation rates, underdeveloped or immature lungs and increased physical activity $[84,85]$. The constituents of airborne pollutants have the ability to interfere with the signaling pathways of a timed sequence of chemical messages that guides lung growth [86]. Researchers have reported that particulate matter exposure affects the functioning and growth of the lungs in children $[87,88]$. They possess an airway epithelium that is permeable to inhaled pollutants [89]. Their poor immunity to PM and exposure to outdoor PM has been linked with increased incidence of Lower Respiratory Tract Infections (LRTIs) [90]. The observed health risks in humans from microbial exposure is dependent on 
the types and concentration of species, metabolic products, exposure duration and susceptibility of individuals [57]. Daily inhalation exposure to low doses of aeroallergens could also weaken mucociliary clearance and the immune system, thus increasing susceptibility to respiratory problems [70].

This study was limited by the culture-dependent method that was adopted. It has been reported that culture-based methods are laborious and can only support the growth of $\sim 10 \%$ of the total microorganisms in an environment [91]. The method assumes that organisms will grow and produce typical characteristics within a specified period. Conversely, culture-dependent methods have been adopted previously in bioaerosols studies [92-94]. It has been used extensively in the collection and identification of microbial diversity [95] and to reflect real-time changes in the types and concentrations of airborne bioaerosols together with changes in environmental conditions $[96,97]$.

\section{Conclusions}

This study gave an insight into the seasonal concentrations of bacterial and fungal types present in $\mathrm{PM}_{2.5}$ and their corresponding inhalation doses in Pretoria West industrial area. Bacterial-bound $\mathrm{PM}_{2.5}$ identified in this study included species of Staphylococcus, Bacillus, Micrococcus, Flavobacterium, Klebsiella and Pseudomonas. Allergenic and pathogenic fungi that were identified included species of Alternaria, Aspergillus, Cladosporium, Fusarium and Penicillium. The concentrations of both bacteria and fungi were lower in winter than in summer. Children are more likely to inhale significantly higher bacterial and fungal doses than infants and adults.

Findings from this study could serve as the basis for other bioaerosols studies looking at the role of the biological fractions of $\mathrm{PM}_{2.5}$ on human health. The information generated could also be used by policymakers and relevant stakeholders in the establishment of regulatory standards pertaining to bioaerosols in the outdoor air. This will assist in the development of an appropriate intervention that will ensure the protection of vulnerable populations from the adverse health effects of exposure to bioaerosol-bound $\mathrm{PM}_{2.5}$.

Author Contributions: Conceptualization, O.M.M., M.I.M. and M.S.M.; methodology, O.M.M., M.I.M., M.S.M. and T.G.; software, T.G.; validation, O.M.M., M.I.M. and M.S.M.; formal analysis, O.M.M. and T.G.; investigation, O.M.M. and T.G.; resources, M.I.M. and M.S.M.; data curation, O.M.M., M.I.M., M.S.M. and T.G.; writing-original draft preparation, O.M.M..; writing —-review and editing, O.M.M., M.I.M., M.S.M. and T.G.; visualization, O.M.M. and T.G.; supervision, M.I.M. and M.S.M.; project administration, O.M.M., M.I.M. and M.S.M.; funding acquisition, M.I.M. and M.S.M.

Funding: This research was funded by the Tshwane University of Technology, Pretoria, South Africa.

Acknowledgments: The authors thank the Air Quality Management, Environment and Agriculture Management Department, City of Tshwane Municipality for allowing us to make use of the Air Quality Monitoring network of the City of Tshwane at the Pretoria West industrial area.

Conflicts of Interest: The authors declare no conflict of interest. The funders had no role in the design of the study, in the collection, analyses, or interpretation of data, in the writing of the manuscript, nor in the decision to publish the results.

\section{References}

1. Brauer, M.; Amann, M.; Burnett, R.T.; Cohen, A.; Dentener, F.; Ezzati, M.; Henderson, S.B.; Krzyzanowski, M.; Martin, R.V.; Dingenen, R.V.; et al. Exposure assessment for estimation of the global burden of disease attributable to outdoor air pollution. Environ. Sci. Technol. 2012, 46, 652-660. [CrossRef] [PubMed]

2. Rorich, R.P.; Galpin, J.S. Air quality in the Mpumalanga Highveld region, South Africa. S. Afr. J. Sci. 1998, 94, 109-114.

3. OECD. OECD Environmental Performance Reviews: South Africa; OECD: Paris, France, 2013.

4. Department of Environmental Affairs and Tourism (DEAT), South Africa. PM 2.5 as an Emerging Priority Pollutant in South Africa-Impacts on Human Health; Paper prepared for Department of Environmental Affairs, Directorate: Information Management; DEAT: Pretoria, South Africa, 2010. 
5. Terblanche, P.; Nel, R.; Golding, T. Household Energy Sources in South Africa: An Overview of the Impact of Air Pollution on Human Health; CSIR Environmental Services, Department of Mineral and Energy Affairs and EMSA (Pty) Ltd.: Pretoria, South Africa, 1994.

6. Wells, R.B.; Lloyd, S.M.; Turner, C.R. National air pollution source inventory. In Air Pollution and Its Impacts on the South African Highveld; Held, G., Gore, B.J., Surridge, A.D., Tosen, G.R., Turner, C.R., Walmsley, R.D., Eds.; Environmental Scientific Association: Johannesburg, South Africa, 1996; pp. 3-9.

7. Blignaut, J.; Zunckel, M. The cost of a decline in air quality. In Sustainable Options, Economic Development Lessons from Applied Environmental Resource Economics in South Africa; Blignaut, J.N., de Wit, M.P., Eds.; Juta and Company Ltd.: Cape Town, South Africa, 2004.

8. South Africa Department of Environmental Affairs and Tourism. National Ambient Air Quality Standard for Particulate Matter with Aerodynamic Diameter less than 2.5 Micron Metres $\left(\mathrm{PM}_{2.5}\right)$. In Government Gazette; National Environmental Management: Nairobi, Kenyan, 29 June 2012; pp. 7-9.

9. Kelly, F.J.; Fussell, J.C. Size, source and chemical composition as determinants of toxicity attributable to ambient particulate matter. Atmos. Environ. 2012, 60, 504-526. [CrossRef]

10. Billet, S.; Garçon, G.; Dagher, Z.; Verdin, A.; Ledoux, F.; Cazier, F.; Courcot, D.; Aboukais, A.; Shirali, P. Ambient particulate matter $\left(\mathrm{PM}_{2.5}\right)$ : Physicochemical characterization and metabolic activation of the organic fraction in human lung epithelial cells (A549). Environ. Res. 2007, 105, 212-223. [CrossRef]

11. Cao, C.; Jiang, W.; Wang, B.; Fang, J.; Lang, J.; Tian, G.; Jiang, J.; Zhu, T.F. Inhalable microorganisms in Beijing's $\mathrm{PM}_{2.5}$ and $\mathrm{PM}_{10}$ pollutants during a severe smog event. Environ. Sci. Technol. 2014, 48, 1499-1507. [CrossRef] [PubMed]

12. Hoek, G.; Krishnan, R.M.; Beelen, R.; Peters, A.; Ostro, B.; Brunekreef, B.; Kaufman, J.D. Long-term air pollution exposure and cardio-respiratory mortality: A review. Environ. Health. 2013, 12, 43-57. [CrossRef] [PubMed]

13. Mehta, S.; Shin, H.; Burnett, R.; North, T.; Cohen, A.J. Ambient particulate air pollution and acute lower respiratory infections: A systematic review and implications for estimating the global burden of disease. Air Qual. Atmos. Health 2013, 6, 69-83. [CrossRef] [PubMed]

14. Rohr, A.C.; Wyzga, R.E. Attributing health effects to individual particulate matter constituents. Atmos. Environ. 2012, 62, 130-152. [CrossRef]

15. Benbrahim-Tallaa, L.; Baan, R.A.; Grosse, Y.; Lauby-Secretan, B.; El Ghissassi, F.; Bouvard, V.; Guha, N.; Loomis, D.; Straif, K. Carcinogenicity of diesel-engine and gasoline-engine exhausts and some nitroarenes. Lancet Oncol. 2012, 13, 663-664. [CrossRef]

16. World Health Organization. A Global Brief on Hypertension; WHO: Geneva, Switzerland, 2013; Available online: http:/ / apps.who.int/iris/bitstream/10665/79059/1/WHO_DCO_WHD_2013.2_eng.pd (accessed on 5 October 2015).

17. Pui, D.Y.H.; Chen, S.; Zuo, Z. PM $_{2.5}$ in China: Measurements, sources, visibility and health effects, and mitigation. Particuology 2014, 13, 1-26. [CrossRef]

18. Morakinyo, O.M.; Mokgobu, M.I.; Mukhola, M.S.; Hunter, R.P. Health outcomes of exposure to Biological and Chemical components of inhalable and respirable particulate matter. Int. J. Environ. Res. Public Health 2016, 13, 592. [CrossRef] [PubMed]

19. Heederick, D.; Thorne, P.S.; Douwes, J. Biological agents monitoring and evaluation of bioaerosol exposure. In International Modern Industrial Hygiene, Volume 2: Biological Aspects; Perkins, J.L., Ed.; American Conference of Governmental Industrial Hygienists, Inc.: Cincinnati, OH, USA, 2003; pp. 93-327.

20. Hargreaves, M.; Parappukkaran, S.; Morawska, L.; Hitchins, J.; He, C.; Gilbert, D. A pilot investigation into associations between indoor airborne fungal and non-biological particle concentrations in residential houses in Brisbane, Australia. Sci. Total Environ. 2003, 312, 89-101. [CrossRef]

21. Ariya, P.A.; Amyot, M. New directions: The role of bioaerosols in atmospheric chemistry and physics. Atmos. Environ. 2004, 38, 1231-1232. [CrossRef]

22. Lighthart, B. The ecology of bacteria in the alfresco atmosphere. FEMS Microbiol. Ecol. 1997, $23,263-274$. [CrossRef]

23. Glikson, M.; Rutherford, S.; Simpson, R.W.; Mitchell, C.A.; Yago, A. Microscopic and submicron components of atmospheric particulate matter during high asthma periods in Brisbane, Queensland, Australia. Atmos. Environ. 1995, 29, 549-562. [CrossRef] 
24. Pillai, S.D.; Ricke, S.C. Review/Synthèse Bioaerosols from municipal and animal wastes: Background and contemporary issues. Can. J. Microbiol. 2002, 48, 681-696. [CrossRef] [PubMed]

25. Kharangate-Lad, A. Bacteria Adhered to Particulate Matter and Their Role in Plant Litter Mineralization. In Bioprospects of Coastal Eubacteria; Springer International Publishing: Cham, Switzerland, 2015.

26. Zhai, Y.; Li, X.; Wang, T.; Wang, B.; Li, C.; Zen, G. A review on airborne microorganisms in particulate matters: Composition, characteristics and influence factors. Environ. Int. 2018, 113, 74-90. [CrossRef]

27. Żukiewicz-Sobczak, W.A. The role of fungi in allergic diseases. Adv. Dermatol. Allergol. 2013, 30, 42-45. [CrossRef]

28. Crameri, R.; Garbani, M.; Rhyner, C.; Huitema, C. Fungi: The neglected allergenic sources. J. Allergy Clin. Immunol. 2014, 69, 176-185. [CrossRef]

29. Peccia, J.; Milton, D.; Reponen, T.; Hill, J.A. Role for environmental engineering and science in preventing bioaerosol-related disease. Environ. Sci. Technol. 2008, 42, 4631-4637. [CrossRef]

30. Moorman, J.E.; Zahran, H.; Truman, B.I.; Molla, M.T. Current asthma prevalence-United States, 2006-2008. MMWR 2011, 60, 84-86.

31. Camatini, M.; Corvaja, V.; Pezzolato, E.; Mantecca, P.; Gualtieri, M. PM10-biogenic fraction drives the seasonal variation of proinflammatory response in A549 cells. Environ. Toxicol. 2012, 27, 63-73. [CrossRef] [PubMed]

32. Longhin, E.; Pezzolato, E.; Mantecca, P.; Holme, J.A.; Franzetti, A.; Camatini, M.; Gualtieri, M. Season linked responses to fine and quasi-ultrafine Milan PM in cultured cells. Toxicol. In Vitro 2013, 27, 551-559. [CrossRef] [PubMed]

33. Thorne, P.S.; Kulhankova, K.; Yin, M.; Cohn, R.; Arbes, S.J., Jr.; Zeldin, D.C. Endotoxin exposure is a risk factor for asthma. Am. J. Respir. Crit. Care Med. 2005, 172, 1371-1377. [CrossRef] [PubMed]

34. Abbing-Karahagopian, V.; van der Gugten, A.C.; van der Ent, C.K.; Uiterwaal, C.; de Jongh, M.; Oldenwening, M.; Brunekreef, B.; Gehring, U. Effect of endotoxin and allergens on neonatal lung function and infancy respiratory symptoms and eczema. Pediatr. Allergy Immunol. 2012, 23, 448-455. [CrossRef] [PubMed]

35. Rabinovitch, N.; Liu, A.H.; Zhang, L.; Rodes, C.E.; Foarde, K.; Dutton, S.J.; Murphy, J.R.; Gelfand, E.W. Importance of the personal endotoxin cloud in school-age children with asthma. J. Allergy Clin. Immunol. 2005, 116, 1053-1057. [CrossRef]

36. Liebers, V.; Raulf-Heimsoth, M.; Brüning, T. Health effects due to endotoxin inhalation (review). Arch. Toxicol. 2008, 82, 203-210. [CrossRef]

37. Schwartz, D.A. Inhaled endotoxin, a risk for airway disease in some people. Respir. Physiol. 2001, 128, 47-55. [CrossRef]

38. Loh, L.C.; Vyas, B.; Kanabar, V.; Kemeny, D.M.; O'Connor, B.J. Inhaled endotoxin in healthy human subjects: A dose-related study on systemic effects and peripheral CD4+ and CD8+ T cells. Respir. Med. 2006, 100, 519-528. [CrossRef]

39. Schwartz, D.A.; Donham, K.J.; Olenchock, S.A.; Popendorf, W.J.; Van Fossen, D.S.; Burmeister, L.F.; Merchant, J.A. Determinants of longitudinal changes in spirometric function among swine confinement operators and farmers. Am. J. Respir. Crit. Care Med. 1995, 151, 47-53. [CrossRef]

40. Thorn, J. The inflammatory response in humans after inhalation of bacterial endotoxin: A review. Inflamm. Res. 2001, 50, 254-261. [CrossRef] [PubMed]

41. World Health Organization. Top 10 Causes of Death. The 10 Leading Causes of Death by Broad Income Group. Factsheet No. 310. Available online: http:/ /www.who.int/mediacentre/factsheets/fs310/en/index. html (accessed on 8 April 2015).

42. Freemaptools. Elevation Finder. Elevation of the City Hall in Pretoria, 4 July 2014. Available online: https:/ / www.freemaptools.com/elevation-finder.htm (accessed on 8 April 2015).

43. Morakinyo, O.M.; Adebowale, S.A.; Mokgobu, M.I.; Mukhola, M.S. Health risk of inhalation exposure to sub-10 $\mu \mathrm{m}$ particulate matter and gaseous pollutants in an urban-industrial area in South Africa: An ecological study. BMJ Open 2017, 7, e013941. [CrossRef] [PubMed]

44. Morakinyo, O.M.; Mokgobu, M.I.; Mukhola, M.S.; Engelbrecht, J.C. Health Risk assessment of exposure to ambient concentrations of Benzene, Toluene, and Xylene in Pretoria West, South Africa. Afr. J. Sci. Technol. Inn. Dev. 2017, 9, 489-496. [CrossRef] 
45. CEN. Ambient Air Quality—Standard Gravimetric Measurement Method for the Determination of the PM 2.5 Mass Fraction of Suspended Particulate Matter. European; Committee for Standardization (EH/2/3); BSI Group: London, UK, 2005; EN 14907.

46. Alghamdi, M.A.; Shamy, M.; Redal, M.A.; Khoder, M.; Awad, A.H.; Elserougy, S. Microorganisms associated particulate matter: A preliminary study. Sci. Total Environ. 2014, 479-480, 109-116. [CrossRef] [PubMed]

47. Mentese, S.; Rad, A.Y.; Arısoy, M.; Güllü, G. Seasonal and spatial variations of bioaerosols in indoor urban environments, Ankara, Turkey. Indoor Built Environ. 2012, 21, 797-810. [CrossRef]

48. Jensen, P.A.; Mohr, A.J.; Schafer, M.P. Instrumentation used with microbial bioaerosol. In Atmospheric Microbial Aerosols: Theory and Applications; Lighthart, B., Mohr, A.J., Eds.; Springer: Boston, MA, USA, 1994; pp. 226-284.

49. Bragoszewska, E.; Mainka, A.; Pastuszka, J.S. Bacterial aerosols in an urban nursery school in Gliwice, Poland: A case study. Aerobiologica 2016, 32, 469-480. [CrossRef]

50. Andersen, A.A. New sampler for the collection, sizing, and enumeration of viable airborne particles. J. Bacteriol. 1958, 76, 471-484. [PubMed]

51. Madureira, J.; Paciência, I.; Rufo, J.C.; Pereira, C.; Teixeira, J.P.; De Oliveira Fernandes, E. Assessment and determinants of airborne bacterial and fungal concentrations in different indoor environments: Homes, child day-care centres, primary schools and elderly care centres. Atmos. Environ. 2015, 109, 139-146. [CrossRef]

52. PN-EN 12322. In Vitro Diagnostic Medical Devices. Culture Media for Microbiology. Performance Criteria for Culture Media; PKN Polish Committee for Standardization (PKN): Warsaw, Poland, 2005.

53. Menetrez, M.Y.; Foarde, K.K.; Esch, R.K.; Schwartz, T.D.; Dean, T.R.; Hays, M.D.; Cho, S.H.; Betancourt, D.A.; Moore, S.A. An evaluation of indoor and outdoor biological particulate matter. Atmos. Environ. 2009, 43, 5476-5483. [CrossRef]

54. Bragoszewska, E.; Biedroń, I.; Kozielska, B.; Pastuszka, J.S. Microbiological indoor air quality in an office building in Gliwice, Poland: Analysis of the case study. Air Qual. Atmos. Health 2018, 11, 729-740. [CrossRef]

55. Bragoszewska, E.; Mainka, A.; Pastuszka, J.; Lizończyk, K.; Desta, Y. Assessment of Bacterial Aerosol in a Preschool, Primary School and High School in Poland. Atmosphere 2018, 9, 87. [CrossRef]

56. United States Environmental Protection Agency. Child-Specific Exposure Factors Handbook; EPA, Environmental Protection Agency: Washington, DC, USA, 2002.

57. United States Environmental Protection Agency. Exposure Factors Handbook; EPA, Environmental Protection Agency: Washington, DC, USA, 2011.

58. Johnson-Restrepo, B.; Kannan, K. An assessment of sources and pathways of human exposure to polybrominated diphenyl ethers in the United States. Chemosphere 2009, 76, 542-548. [CrossRef]

59. Matooane, M.; Diab, R. Health risk assessment for sulfur dioxide pollution in South Durban, South Africa. Arch. Environ. Health Int. J. 2003, 58, 763-770. [CrossRef] [PubMed]

60. United States Environmental Protection Agency (US EPA); National Center for Environmental Assessment, Office of Research and Development; U.S. Environmental Protection Agency. Exposure Factors Handbook. Available online: http:/ / www.epa.gov/ncea/expofac.htm. (accessed on 20 June 2015).

61. Mouzourides, P.; Kumar, P.; Neophytou, M.K.A. Assessment of long-term measurements of particulate matter and gaseous pollutants in South-East Mediterranean. Atmos. Environ. 2015, 107, 148-165. [CrossRef]

62. Fröhlich-Nowoisky, J.; Burrows, S.M.; Xie, Z.; Engling, G.; Solomon, P.A.; Fraser, M.P.; Mayol-Bracero, O.L.; Artaxo, P.; Begerow, D.; Conrad, R.; et al. Biogeography in the air: Fungal diversity over land and oceans. Biogeosci. Discuss. 2011, 8, 7071-7096. [CrossRef]

63. Handley, B.A.; Webster, A.J.F. Some factors affecting the airborne survival of bacteria outdoors. J. Appl. Bacteriol. 1995, 79, 368. [CrossRef] [PubMed]

64. Fang, Z.; Ouyang, Z.Y.; Zheng, H.; Wang, X.; Hu, L. Culturable airborne bacteria in outdoor environments in Beijing, China. Microb. Ecol. 2007, 54, 487-496. [CrossRef]

65. Aydogdu, H.; Asan, A.; Otkum, M.T. Indoor and outdoor airborne bacteria in child day-care centers in Edirne City (Turkey), seasonal distribution and influence of meteorological factors. Environ. Monit. Assess. 2010, 164, 53. [CrossRef] [PubMed]

66. Menteşe, S.; Arisoy, M.; Rad, A.Y.; Güllü, G. Bacteria and fungi levels in various indoor and outdoor environments in Ankara, Turkey. Clean Soil Air Water 2009, 37, 487-493. [CrossRef] 
67. Ren, P.; Jankun, T.M.; Leaderer, B.P. Comparisons of seasonal fungal prevalence in indoor and outdoor air and in house dusts of dwellings in one Northeast American county. J. Expo. Sci. Environ. Epidemiol. 1999, 9, 560-568. [CrossRef]

68. Pyrri, I.; Kapsanaki-Gotsi, E. Diversity and annual fluctuations of culturable airborne fungi in Athens, Greece: A 4-year study. Aerobiologia 2012, 28, 249-262. [CrossRef]

69. Salonen, H.; Duchaine, C.; Mazaheri, M.; Clifford, S.; Morawska, L. Airborne culturable fungi in naturally ventilated primary school environments in a subtropical climate. Atmos. Environ. 2015, 106, 412-418. [CrossRef]

70. AbdeLHameed, A.A.; Khoder, M.I.; Ibrahim, Y.H.; Saeed, Y.; Osman, M.E.; Ghanem, S. Study on some factors affecting survivability of airborne fungi. Sci. Total Environ. 2012, 414, 696-700. [CrossRef] [PubMed]

71. Kuhn, D.M.; Ghannoum, M.A. Indoor mold, toxigenic fungi, and Stachybotrys chartarum: Infectious disease perspective. Clin. Microbiol. Rev. 2003, 16, 144-172. [CrossRef] [PubMed]

72. Knutsen, A.P.; Bush, R.K.; Demain, J.G.; Denning, D.W.; Dixit, A.; Fairs, A.; Greenberger, P.A.; Kariuki, B.; Kita, H.; Kurup, V.P.; et al. Fungi and allergic lower respiratory tract diseases. J. Allergy Clin. Immunol. 2012, 129, 280-291. [CrossRef] [PubMed]

73. Ege, M.J.; Mayer, M.; Normand, A.C.; Genuneit, J.; Cookson, W.O.; Braun-Fahrländer, C.; Heederik, D.; Piarroux, R.; Von Mutius, E. Exposure to environmental microorganisms and childhood asthma. N. Engl. J. Med. 2011, 364, 701-709. [CrossRef]

74. Raisi, L.; Aleksandropoulou, V.; Lazaridis, M.; Katsivela, E. Size distribution of viable, cultivable, airborne microbes and their relationship to particulate matter concentrations and meteorological conditions in a Mediterranean site. Aerobiologia 2013, 29, 233-248. [CrossRef]

75. Zhong, X.; Qi, J.; Li, H.; Dong, L.; Gao, D. Seasonal distribution of microbial activity in bioaerosols in the outdoor environment of the Qingdao coastal region. Atmos. Environ. 2016, 140, 506-513. [CrossRef]

76. Lee, B.U.K.; Lee, G.; Heo, K.J. Concentration of culturable bioaerosols during winter. J. Aerosol Sci. 2016, 94, 1-8. [CrossRef]

77. Li, Y.; Lu, R.; Li, W.; Xie, X.; Song, Y. Concentrations and size distributions of viable bioaerosols under various weather conditions in a typical semi-arid city of Northwest China. J. Aerosol Sci. 2017, 106, 83-92. [CrossRef]

78. Gao, M.; Qiu, T.; Jia, R.; Han, M.; Song, Y.; Wang, X. Concentration and size distribution of viable bioaerosols during non-haze and haze days in Beijing. Environ. Sci. Pollut. Res. 2015, 22, 4359-4368. [CrossRef] [PubMed]

79. Ulevicius, V.; Peciulyte, D.; Mordas, G.; Lugauskas, A. Field study on changes in viability of airborne fungal propagules exposed to solar radiation. J. Aerosol Sci. 2000, 31, 961-962. [CrossRef]

80. Hwang, G.B.; Jung, J.H.; Jeong, T.G.; Lee, B.U. Effect of hybrid UV-thermal energy stimuli on inactivation of S. epidermidis and B. subtilis bacterial bioaerosols. Sci. Total Environ. 2010, 408, 5903-5909. [CrossRef] [PubMed]

81. Bragoszewska, E.; Mainka, A.; Pastuszka, J.S. Bacterial and Fungal Aerosols in Rural Nursery Schools in Southern Poland. Atmosphere 2016, 7, 142. [CrossRef]

82. Mainka, A.; Zajusz-Zubek, E. Indoor Air quality in urban and rural preschools in Upper Silesia, Poland: Particulate Matter and carbon dioxide. Int. J. Environ. Res. Public Health 2015, 12, 7697-7711. [CrossRef] [PubMed]

83. Annesi-Maesano, I.; Baiz, N.; Banerjee, S.; Rudnai, P.; Rive, S. Indoor air quality and sources in schools and related health effects. J. Toxicol. Environ. Health B 2013, 16, 491-550. [CrossRef] [PubMed]

84. Salvi, S. Health effects of ambient air pollution in children. Paediatr. Respir. Rev. 2007, 8, 275-280. [CrossRef] [PubMed]

85. Schnabel, E.; Sausenthaler, S.; Brochow, I.; Liese, J.; Herbarth, O.; Michael, B.; Schaaf, B.; Kramer, U.; von Berg, A.; Wichmann, H.E.; et al. LISA Study Group. Burden of otitis media and pneumonia in children up to 6 years of age: Results of the LISA birth cohort. Eur. J. Pediatr. 2009, 168, 1251-1257. [CrossRef]

86. Trasande, L.; Thurston, G.D. The role of air pollution in asthma and other pediatric morbidities. J. Allergy Clin. Immunol. 2005, 115, 689-699. [CrossRef]

87. Oftedal, B.; Brunekreef, B.; Nystad, W.; Madsen, C.; Walker, S.; Nafstad, P. Residential outdoor air pollution and lung function in schoolchildren. Epidemiology 2008, 19, 129-137. [CrossRef] 
88. Gauderman, W.J.; McConnell, R.; Gilliland, F.; London, S.; Thomas, D.; Avol, E.; Vora, H.; Berhane, K.; Rappaport, E.B.; Lurmann, F.; et al. Association between air pollution and lung function growth in southern California children: Results from a second cohort. Am. J. Respir. Crit. Care Med. 2002, 166, 76-84. [CrossRef] [PubMed]

89. Schwartz, J. Air pollution and children's health. Pediatrics 2004, 113, 1037-1043. [PubMed]

90. Wald, E.R. Recurrent and nonresolving pneumonia in children. Semin. Respir. Infect. 1993, 8, 46-58. [PubMed]

91. Després, V.R.; Huffman, J.A.; Burrows, S.M.; Hoose, C.; Safatov, A.S.; Buryak, G.; Fröhlich-Nowoisky, J.; Elbert, W.; Andreae, M.O.; Pöschl, U. Primary biological aerosol particles in the atmosphere: A review. Tellus Ser. B Chem. Phys. Meteorol. 2012, 64, 15598. [CrossRef]

92. Fang, Z.; Ouyang, Z.; Zheng, H.; Wang, X. Concentration and size distribution of culturable airborne microorganisms in outdoor environments in Beijing, China. Aerosol Sci. Technol. 2008, 42, 325-334. [CrossRef]

93. Gao, M.; Jia, R.; Qiu, T.; Han, M.; Song, Y.; Wang, X. Seasonal size distribution of airborne culturable bacteria and fungi and preliminary estimation of their deposition in human lungs during non-haze and haze days. Atmos. Environ. 2015, 118, 203-210. [CrossRef]

94. Hu, L.F.; Zhang, K.; Wang, H.B.; Li, N.; Wang, J.; Yang, W.H.; Yin, Z.; Jiao, Z.G.; Wen, Z.B.; Li, J.S. Concentration and Particle Size Distribution of Microbiological Aerosol During Haze Days in Beijing. Huan Jing Ke Xue 2015, 36, 3144-3149. [PubMed]

95. Pitkäranta, M.; Meklin, T.; Hyvärinen, A.; Nevalainen, A.; Paulin, L.; Auvinen, P.; Lignell, U.; Rintala, H. Molecular profiling of fungal communities in moisture damaged buildings before and after remediation-A comparison of culture-dependent and culture-independent methods. BMC Microbiol. 2011, 11, 235. [CrossRef] [PubMed]

96. Haas, D.; Galler, H.; Luxner, J.; Zarfel, G.; Buzina, W.; Friedl, H.; Marth, E.; Habib, J.; Reinthaler, F.F. The concentrations of culturable microorganisms in relation to particulate matter in urban air. Atmos. Environ. 2013, 65, 215-222. [CrossRef]

97. Dybwad, M.; Skogan, G.; Blatny, J.M. Temporal variability of the bioaerosol background at a subway station: Concentration level, size distribution, and diversity of airborne bacteria. Appl. Environ. Microbiol. 2014, 80, 257-270. [CrossRef] [PubMed] 